\title{
Field School of Organic Farming as an Effort to Increase Organic Rice Production
}

\author{
Yaya Hasanah $^{* 1)}$, Hamidah Hanum ${ }^{1)}$, Herla Rusmarilin ${ }^{1)}$ \\ Agrotechnology Department, Faculty of Agriculture, Universitas Sumatera Utara, Padang Bulan Medan \\ 20155
}

\begin{abstract}
The increase in people's healthy lifestyle has increased the demand for organic rice. However, this is not supported by sufficient increase in the organic rice production. Therefore, Field School of Organic Farming (FS-OF) was conducted as an effort to increase the organic rice production. This FS-OF activity is aimed to improve farmers' understanding and skill about the organic rice cultivation through demonstration plots. The service activities that have been carried out include the production of demonstration plots for organic and conventional rice cultivation to compare their production, handover of technology transfer tools, training in organic rice cultivation, making the liquid organic fertilizers and organic pesticides, and biochar. The results of community service have increased the understanding of field school participants and increased organic rice production by $10 \%$ when compared to conventional rice cultivation.
\end{abstract}

Keywords: Rice, Organic, Field school, Farming

Abstrak. Peningkatan gaya hidup sehat pada masyarakat telah meningkatkan permintaan akan beras organik. Akan tetapi, hal ini tidak didukung oleh cukupnya peningkatan dalam produksi beras organik. Oleh karena itu, Sekolah Lapangan Pertanian Organik (SL-PO) dilakukan sebagai upaya untuk meningkatkan produksi beras organik. Kegiatan SL-PO ini bertujuan untuk meningkatkan pemahaman dan keterampilan petani tentang budidaya padi organik melalui demplot percontohan. Kegiatan pengabdianmasyarakatyang telah dilakukan meliputi demplot budidaya padi organik yang dibandingkan dengan budidaya padi secara konvensional, serah terima barang alih teknologi, pelatihan penanaman padi organik, pembuatan pupuk organik cair dan pestisida organik, dan biochar. Hasil pengabdian masyarakat telah meningkatkan pemahaman peserta sekolah lapangan dan meningkatkan produksi beras organik sebesar $10 \%$ jika dibandingkan dengan budidaya padi konvensional.

Kata Kunci: Beras, Organik, Sekolah lapang, Pertanian

Received 24 September 2019 | Revised 8 October 2019 | Accepted 10 November 2019 *Corresponding author at: Faculty of Agriculture, Universitas Sumatera Utara, Padang Bulan Medan

E-mail address: yaya@usu.ac.id 


\section{Introduction}

The increased growth of public awareness for healthy lifestyles marked by a trend to "back to nature" has resulted in increasing consumption of organic food. The public is increasingly aware of the negative effects of chemical fertilizers, chemical pesticides and growth hormones in agricultural production for health and the environment [2]. Until now, a healthy lifestyle has been institutionalized internationally which requires a guarantee that agricultural products must have safe consumption (food safety attributes), high nutritional attributes (nutritional attributes) and environmentally friendly (eco-labeling attributes) [3].

Public interest in healthy lifestyles has led to an increase in demand for global organic agricultural products by $20 \%$ per year. Organic rice as staple food has also sharply increased its demand, resulting in a gap between demand and organic rice production. Organic rice is rice derived from organic rice, produced through an organic cultivation process, planted on environmentally safe soil, not using chemical fertilizers and pesticides and growth hormones from the beginning of planting to becoming rice that is ready for consumption. Organic rice cultivation is also intended to improve the sustainability and balance of the ecosystem and environmentally friendly.

The organic rice produced by the Mekar Pasar Kawat farmer group has a comparative advantage compared to non-organic rice, because it has passed organic certification (LSO LeSOS), broad market demand, distinctive and delicious organic rice tastes, the selling price of organic rice is very stable, motivation farmers are very enthusiastic about organic farming, and the cost of producing organic rice is cheaper than non-organic rice

Based on the analysis of the situation above and along with the transition of community lifestyles towards organic lifestyles, the problem that occurs is the gap between between organic rice production and market demand, as well as the lack of understanding, knowledge and information that farmers possess in comprehensive organic farming cultivation, so that it still there are concerns farmers about crop failure if they switch from non-organic (conventional) rice cultivation to organic rice cultivation.

Until now, organic farmer groups have only been able to meet the demand for organic rice for a limited circle because of limited production. Until now the Mekar Pasar Kawat Farmer Group has only been able to produce 1.5 to per month of Pandan Wangi and Ciherang. While demand has now reached 3.5 tons per month.herefore, it is necessary to 
increase organic rice production through expansion of the area of organic rice cultivation on other farmer groups' land which is very potential in terms of land area (197.54 ha) in Karang Anyar Village, Deli Serdang that has not yet cultivated organic rice.

\section{Methods}

Based on the analysis of the situation and the problems mentioned above, efforts are needed to overcome the limitations of organic rice production and the lack of understanding, knowledge and information for farmers about organic rice cultivation. The solution to the problem is also expected to develop organic rice and improve sustainable agriculture (environmentally sustainable agriculture) through the Organic Agriculture Field School (OA-FS). Organic farming is an agricultural cultivation technique that uses natural ingredients and does not use synthetic chemicals. The main goal of organic farming is to provide agricultural products, especially food that is safe for the health of producers and consumers, and does not damage the environment [4].

The OA-FS activities one of the agricultural development programs that applies the model of farmer empowerment by increasing the quality and capacity of farmers through the acceleration of adoption of organic farming cultivation technology that all teaching and learning processes are carried out in the field. In OA-FS, the joint learning process carried out in farmers' paddy fields as a field laboratory, aids and the main source of information for organic rice cultivation practices are directly used during the learning process. Through OA-FS obtained effective learning to study organic rice cultivation influenced by the local ecosystem.

At the OA-FS, various training and practices were carried out on the stages of organic rice cultivation, from seeding, planting, making biochar from rice waste, making liquid organic fertilizer and organic pesticides, harvesting and post-harvesting, agribusiness business opportunities that accompany each stage of rice cultivation. Organic, as well as direct practice (field laboratory) organic rice cultivation compared to conventional (non-organic) rice cultivation. It is expected that with this field school there will be an increase in understanding of farmers in organic rice cultivation, so farmers are interested in practicing organic rice cultivation and in turn there will be an increase in organic rice production.

Solving this problem will also create business opportunities from upstream to downstream in organic rice cultivation by empowering farmer groups. With the existence of business opportunities in organic rice cultivation, members of the farmer group not only benefit from the sale of organic rice, but also from the accompanying 
home industries such as making biochar from rice waste, making liquid organic fertilizer and organic pesticides. If one hectare of paddy field produces 6 tons of dried unhusked rice, it will also produce 6 tons of straw waste products and 1.2 tons of rice husk. Total rice production waste for biochar reaches $120 \%$ of the grain [5], [6].

\section{Results and Discussion}

Based on the results of activities in the form of a series of training and direct practice of organic rice cultivation and farmer group bookkeeping training it was revealed that members of the farmer group still need to increase knowledge about organic rice cultivation and opportunities to increase organic rice production. The community still needs to improve their understanding of the use of rice waste into biochar, how to increase production.

Based on the results of the demonstration plot in the field laboratory it is known that the yield from organic rice cultivation is higher than conventional rice cultivation, which are $485 \mathrm{~kg} / 400 \mathrm{~m}^{2}$ and $460 \mathrm{~kg} / \mathrm{m}^{2}$ respectively.

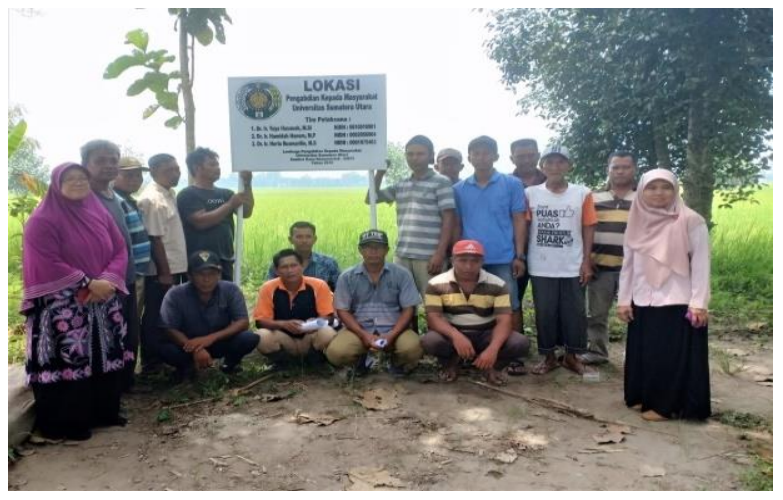

Figure 1. Location of the activity community Service

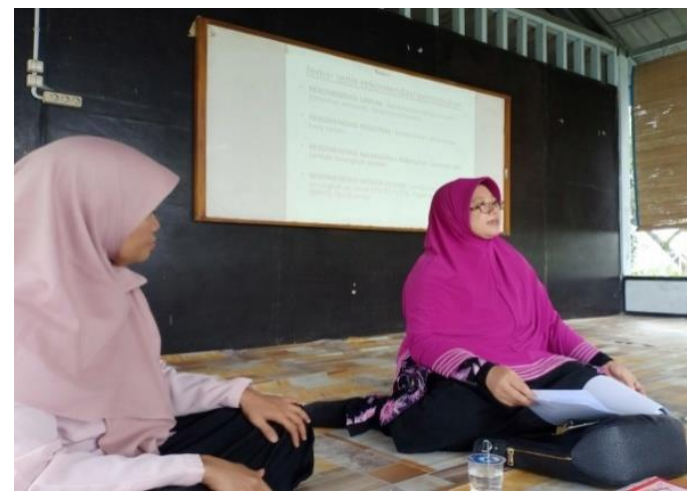

Figure 2. Training on FS-OF
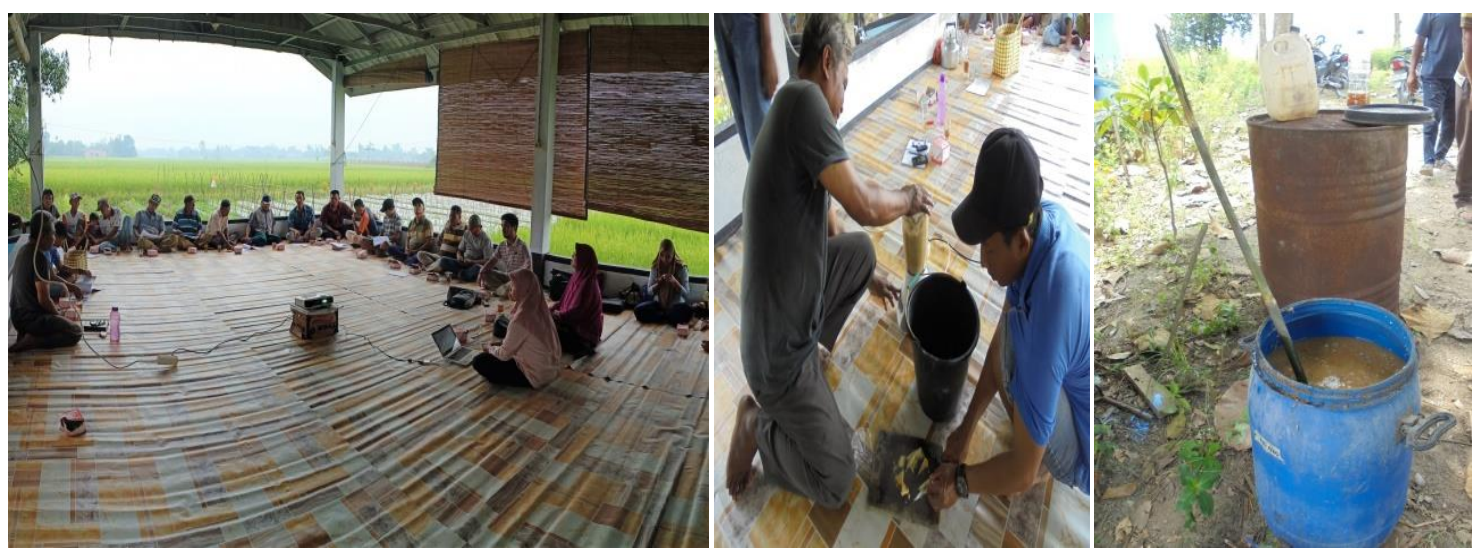

Figure 3. Participants were enthusiastic Figure 4. The practice of making liquid organic in participating in OA-FS fertilizer 


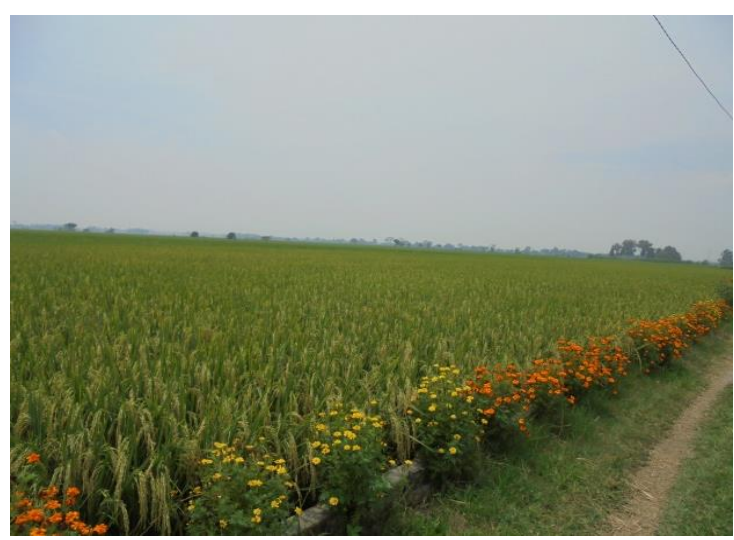

Figure 5. Organic rice demonstration plot

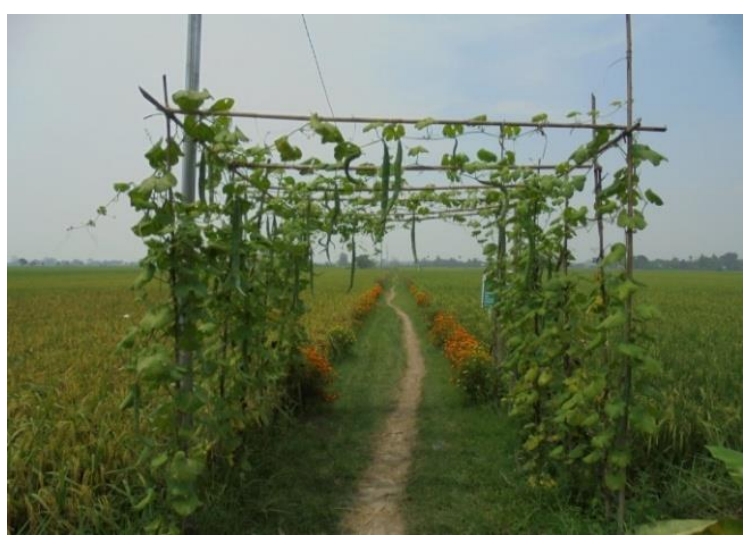

Figure 6. Organic rice fields

At the present, there are already 23 hectares of rice land in KarangAnyar Village that have received organic certification. To get an organic label is not easy, because it must pass the requirements starting from the internal control system, have records of land management, water, fertilization, use of organic pesticides and also natural pest control. Products can be called organic after 2 years managed organically. The implementation of FS-OF increased the interest of farmers to cultivate organic rice because they have understood to produce organic rice.

\section{Conclusions}

Community service activities have been carried out well to increase the understanding of organic farming field school participants. Community farmers as participants in organic farming field schools are very enthusiastic in carrying out this activity. This activity has increased farmers' understanding about organic rice cultivation, as well as the production.

\section{Acknowledgement}

This Community service was supported by a grant from Directorate of Research and Community Service, Directorate General of Research and Technology Strengthening Ministry of Research, Technology and Higher Education in accordance with Contracts for Implementation of Community Service Programs Number: 097/SP2H/PPM/DRPM/2019, March 18, 2019.

\section{References}

[1] Biro Pusat Statistik (Central Bureau of Statistics). 2017. Kecamatan Beringin dalam Angka. (Beringin District in Number). Biro Pusat Statistik Deli Serdang, Sumatera Utara.

[2] Sulistyana, P., J.H. Mulyo dan Jamhari. 2014. Konsumsi Beras Organik Pada Tingkat Rumah Tangga Di Kota Yogyakarta (Consumption of Organic Rice at household level in Yogyakarta City). Agro Ekonomi, Vol. 24(1) : 25-34. 
[3] International Federation of Organic Agriculture Movement. 2012. www. ifoam.org.

[4] Yuliati, L.N. dan Retnaningsih. 2012. Sikap Konsumen Terhadap Beras Organik (Consumer Attitudes toward Organic Rice). Jurnal Manajemen \& Agribisnis, Vol. 9(2): 117-126.

[5] Assai, H., B.K. Samson, H.M. Stephan, K. Songyikhangsuthor, K. Homma, Y. Kiyono. 2009. Biochar amandement techniques for upland rice production in Northern Laos. 1. Soil Physical properties, leaf SPAD and grain yiels. Field Crop Research, 111: 81-84.

[6] Lehmann, J. and S. Joseph. 2009. Biochar for Environmental Management Science and Technology. Earthscan in the UK and U. 